
BARTŁOMIEJ DROP ${ }^{3}$

\title{
Nurse care quality and hospital-acquired infections: adhering to aseptic techniques
}

\begin{abstract}
Introduction. The quality of medical services can be regarded as an indication of the changes being implemented at a given moment. At the same time, improving the care quality remains essential, regardless of the current situation. This makes upgrading employees' skills a necessity, for instance by preventing undesired events, like hospital acquired infections which are quite common.

Aim. The aim of this study was to measure the quality of nursing care delivered to patients who contracted a hospitalacquired disease, with special attention paid to the adherence by aseptic procedures.

Material and methods. The authors of this research study want to assess the quality of nursing care, looking through the lens of adherence by aseptic techniques.

Results. The study was conducted in hospitals of three different referral levels. Both the highest $(=95.7 \%)$ and the lowest $(=84.7 \%)$ rates in the field of quality of nursing care were reported in provincial hospitals.

Conclusion. 1.There is a $10 \%$ deficit in terms of adherence to aseptic procedures. 2. Constant supervision and upgrading nursing staff skills is essential.
\end{abstract}

Keywords: prevention of hospital-acquired infections, adherence by aseptic techniques, quality of care.

DOI: $10.1515 /$ pjph-2015-0040

\section{INTRODUCTION}

The social expectations for health care do not only concern introducing new, improved medical procedures in the future but also put an emphasis on the health care delivered at the moment. This new approach requires introducing effective measures improving the care quality and putting patient first.

The concern about quality has always been a part of human life. Between the 1960s and 1970s, the issues related to quality have become a separate field of knowledge, known as Total Quality Management [1,2]. Healthcare is a field where quality of the provided services is of utmost importance. This is because quality of healthcare services has an impact over human health and even life. This means, any mistakes, negligence or malpractice can have tragic and irreversible consequences [3].

It is the nurse who serves as the communicator between the patient and the healthcare system. Nurses play various roles which depend on the patients' needs at the moment. They fulfill their roles in the closest and most intimate contact with the care receiver, which means that the quality of nurses' work has direct impact on the overall quality of care a patient receives. This calls for further exploration of patients' needs or expectations [4].

The changes that the healthcare market has undergone in recent years called for regulating the market of health ser- vices. Quality assurance is what these changes are supposed to provide, as well as improving the quality. In fact, these two are essential, regardless of the changes in the system. Assessing the changes in social awareness, particularly those regarding patients' awareness about their rights, as well as the level of their expectations or requirements are inextricably linked to nursing, which calls for the need of constant skill upgrading by the nursing staff [5].

According to Fawcett-Henessy, quality should not only become another trend recommended by various organizations, but rather be rooted in a common initiative of all healthcare employees, hoping to improve the quality of services and making care available to anyone who needs it $[6,7]$.

The standards of preventing hospital-acquired infections should make patients, hospital managers, as well as healthcare providers aware of what a high quality care is and what role should they play to improve the care efficiency, particularly in terms of prevention and control of hospital-acquired infections.

\section{AIM}

The aim of this study was to measure the quality of nursing care delivered to patients who contracted a hospitalacquired disease, with special attention paid to the adherence by aseptic procedures.

\footnotetext{
${ }^{1}$ Independent Public Health Care Unit in Kraśnik, Poland

${ }^{2}$ Faculty of Nursing and Health Sciences, Medical University of Lublin, Poland

${ }^{3}$ Department of Public Health, Medical University of Lublin, Poland
} 


\section{MATERIAL AND METHODS}

The research was conducted in 9 hospitals located in the following provinces: the Lubelskie Province, the Podkarpackie Province, the Małopolskie Province. The hospitals included in the study were: 3 county hospitals, 3 provincial hospitals and 3 clinical hospitals. The study was carried out in 56 hospital wards, 27 of which were surgical wards, 20 were medical treatment wards and 9 were intensive care units. The authors undertook 450 research procedures (50 in every hospital).

A self-constructed research tool named ,A chart for measuring the quality of nursing care in the prophylaxis of hospital-acquired infections" was used for the study and it was later assessed using the inter-judge reliability method. Care activities used for prevention of hospital-acquired activities were used as the criteria (used as a reference to particular organs and systems). There are 9 main criteria, with 83 more detailed criteria (a total of 349 points). The sheet contained sections describing the actual situation, for instance "Yes", "No", "Not applicable". The "Yes" section was used for checking the compatibility of a given criterion with the situation at hand. In case any incompatibility was found, the weight of a given criterion was given under the "No" section. The section "Not applicable" was used for situations where a given criterion was not applicable to the given ward or patient. In case a criterion were fulfilled only to some extent, it was possible to disclose the information about its weight between the "Yes" and "No" sections. Later, each ward received a mark for the care quality it delivered - a relationship between the expectations and the actual care quality.

\section{RESULTS}

The first research criterion Adherence to aseptic procedures, comprised of 9 detailed criteria, providing some description of the actions undertaken to provide the highest aseptic standards in a hospital. An analysis of the adherence to aseptic standards was conducted in all healthcare institutions previously looked at - from clinical hospitals, to regional ones. A statistical compilation considering every hospital's referral level (surgical and medical treatment ones) is provided in Table 1.

In clinical hospitals, the nursing care quality coefficients were higher in case of treatment units $(=91.2)$ than in case of surgical wards $(=88.7)$. Regarding the two criteria, namely Open containers (e.g. dropper bottles, ointments, ampoules) contain information about when they were open (exact date and time) and they are secured with a swab (criterion 6) and Open dropper bottles, ointments and ampoules are used within 48 hours (criterion 7) as well as Non-disposable glasses are disinfected and sterilized after each use (criterion 9), the care quality coefficient was higher in case of treatment wards $(87.9 \%, 76.1 \%$ and $83.8 \%$ respectively) than surgical ones $(78.4 \%, 75.1 \%$ and $80.0 \%)$. These differences were statistically significant for criterion 6 and 7 , by $\alpha=0.01$. However, there were some inadequacies pertaining to criterion 8 (Oral medication is supplemented with disposable glasses) and criterion 5 .

TABLE 1. Adherence to aseptic standards (I) at treatment and surgical wards in hospitals at all referral levels.

\begin{tabular}{|c|c|c|c|c|c|c|c|c|c|c|}
\hline \multirow{4}{*}{ Detailed criteria } & \multicolumn{10}{|c|}{ Wards } \\
\hline & \multicolumn{5}{|c|}{ surgical } & \multicolumn{5}{|c|}{ treatment } \\
\hline & \multicolumn{5}{|c|}{ Nursing care quality } & \multicolumn{5}{|c|}{ Nursing care quality } \\
\hline & $\mathbf{K}$ & $\mathbf{W}$ & $\mathbf{P}$ & $\chi^{2}$ & $\alpha$ & $\mathbf{K}$ & $\mathbf{W}$ & $\mathbf{P}$ & $\chi^{2}$ & $\alpha$ \\
\hline \multicolumn{11}{|l|}{ I. Adherence to aseptic standards } \\
\hline 1. The nurse washes and disinfects their hands prior to any action & 95.9 & 93.7 & 98.1 & 0.00 & 1.00 & 92.9 & 97.9 & 95.6 & 0.00 & 1.00 \\
\hline 2. The nurse wears protective gloves when dealing with the patient & 97.9 & 94.6 & 99.1 & 0.00 & 1.00 & 92.1 & 97.9 & 97.5 & 0.00 & 1.00 \\
\hline 3. Disposable medical products have not exceeded their expiry date & 99.3 & 99.3 & 99.2 & 0.00 & 1.00 & 94.6 & 98.2 & 95.2 & 0.00 & 1.00 \\
\hline $\begin{array}{l}\text { Disposable medical products are stored in a way that prevents } \\
\text { any dampness problems or damage }\end{array}$ & 97.9 & 100.0 & 97.1 & 0.00 & 1.00 & 96.8 & 92.1 & 94.6 & 2.00 & 0.16 \\
\hline $\begin{array}{l}\text { Drugs prepared in the dispensary are used according } \\
\text { to the dispensary's recommendations }\end{array}$ & 98.5 & 96.1 & 97.6 & 0.00 & 1.00 & 87.5 & 93.8 & 95.5 & 0.00 & 1.00 \\
\hline $\begin{array}{l}\text { Open containers (e.g. dropper bottles, ointments, ampoules) contain } \\
\text { 6. information about when they were open (exact date and time) } \\
\text { and they are secured with a swab }\end{array}$ & 78.4 & 88.7 & 91.1 & 3.09 & 0.08 & 87.9 & 92.9 & 91.8 & 6.63 & 0.01 \\
\hline $\begin{array}{l}\text { 7. Open dropper bottles, ointments and ampoules are used } \\
\text { within } 48 \text { hours }\end{array}$ & 75.1 & 81.3 & 69.4 & 0.97 & 0.32 & 76.1 & 80.0 & 77.8 & 6.62 & 0.01 \\
\hline 8. Oral medication is supplemented with disposable glasses & 97.8 & 91.8 & 65.1 & 0.50 & 0.48 & 86.5 & 99.5 & 74.6 & 3.38 & 0.07 \\
\hline 9. Non-disposable glasses are disinfected and sterilized after every use & 80.0 & 82.5 & 89.6 & 0.00 & 1.00 & 83.8 & 68.6 & 88.1 & 0.00 & 1.00 \\
\hline Mean \% 0 & 91.2 & 92.0 & 89.6 & & & 88.7 & 91.2 & 90.1 & & \\
\hline Total W.O.P. & & & 90.9 & & & & & 90.0 & & \\
\hline$\chi^{2}$ & & & 94.71 & & & & & 53.58 & & \\
\hline$\alpha$ & & & 00000 & & & & & 00000 & & \\
\hline
\end{tabular}

Explanation:

$\mathrm{K}$ - clinical hospitals

$\mathrm{W}$ - provincial hospitals

$\mathrm{P}$ - district hospitals
W.O.P. - nursing care quality coefficient

$\chi^{2}-$ Chi-square

$\alpha$-asymptotic significance, Friedman test 
There were some noticeable gaps regarding fulfilling the procedures in treatment wards, It was clear in case of the following criteria: Oral medication is supplemented with disposable glasses (criterion 8) - 86.5\% and Drugs prepared in the dispensary are used according to the dispensary's recommendations (criterion 5) $-87.5 \%$. The level of statistical significance for criterion 8 was $\alpha=0.07$ for treatment wards and $\alpha=0.48$ for surgical wards.

In case of surgical wards, when compared to treatment wards, the lowest care coefficient was reached for criterion 7 - Open dropper bottles, ointments and ampoules are used within 48 hours $-75.1 \%$ and criterion 6 Open containers (e.g. dropper bottles, ointments, ampoules) contain information about when they were open (exact date and time) and they are secured with a swab-78.4\%, The differences in case of criterion 6 and criterion 7 were as follows: for surgical wards: 0.08 and $\alpha=0.32$, while for treatment wards it was $\alpha=0.01$ for both.

At medical treatment wards in provincial hospitals, the questionnaire revealed a low care coefficient for the criterion 7 Open dropper bottles, ointments and ampoules are used within 48 hours $-80.0 \%$, like it is the case with surgical wards $-81.3 \%$. It was a statistically significant difference for medical treatment wards $(\alpha=0.01)$. For surgical wards, the difference was not statistically significant $\alpha=0.32$. The lowest care coefficient was reached for point 9 Non-disposable glasses are disinfected and sterilized after each use $-68.6 \%$ (a non-statistically significant difference). The mean nurse care coefficient (for the 9 detailed criteria) was similar both in case of treatment wards $(=91.2 \%)$ and surgical wards $(92.0 \%)$.

The results obtained in the field of adherence to aseptic procedures (I) in regional hospitals show that the nursing care quality coefficient was the lowest in case of the following criteria - criterion 7 Open dropper bottles, ointments and ampoules are used within 48 hours (criterion 7) - 69.4\% and Oral medication is supplemented with disposable glasses (criterion 8) - 65.1\%. These differences had no statistical significance. In case of treatment wards, the lowest coefficient was noticed in case of criterion $8-74.6 \%$. This difference had no statistical significance $(\alpha=0.07)$.
The results obtained show that the nursing care quality coefficient was the lowest for criterion 7, which is Open dropper bottles, ointments and ampoules are used within 48 hours. There were some statistically significant differences $(p<0,05)$ with regards to the criterion 6 and 7 on treatment wards, while in case of surgical wards there were no statistically significant differences $(p<0.05)$. The above-mentioned analysis shows some statistically significant differences in terms of adhering to various aseptic procedures on treatment wards in these hospitals. Also, when the mean care quality coefficient is taken into account $(90.9 \%$ for surgical wards, $90.0 \%$ for treatment wards), there were some statistically significant differences: for surgical wards $\alpha=0.00000001$, for treatment wards $\alpha=0.00000001$

An analysis of the findings shows that there are some statistically significant differences $(p<0.05)$ in terms of the adherence to aseptic procedures in the surveyed hospitals (Table 2). With the mean care quality coefficient (in case of all hospitals) being $90.6 \%$, both the lowest and the highest ones were obtained in provincial hospitals $-84.7 \%$ and $95.7 \%$ respectively, with the statistical significance level at $\mathrm{H}=0.00028$. The highest mean coefficient was reported in case of hospitals of the second referral level (91.4\%) and the lowest (89.7\%) in case of hospitals of the third referral level.

\section{DISCUSSION}

Hospital-acquired infections are puzzling both health care professionals and the public. Understanding these issues requires the knowledge in the fields of epidemiology, infectious diseases, microbiology, as well as the economy or management. The ability to prevent hospital-acquired infections is regarded as the most important care quality indicator [8-10].

An analysis of the material shows that proper education of the staff, including the development of the right hygiene and epidemiological habits can greatly help the adherence to aseptic standards.

An investigation of a large group of nurses, conducted by Polish Epidemiological Nurses Association shows that during the procedure of flushing the venous catheter, some $44 \%$ of nurses did not adhere to any aseptic procedures,

TABLE 2. The value of nursing care quality coefficient in terms of adherence to aseptic procedures in hospitals analyzed in the study.

\begin{tabular}{|c|c|c|c|c|c|c|c|c|c|c|}
\hline & \multicolumn{9}{|c|}{ Types of hospitals } & \multirow{3}{*}{ Total } \\
\hline & \multicolumn{3}{|c|}{ clinical } & \multicolumn{3}{|c|}{ provincial } & \multicolumn{3}{|c|}{ district } & \\
\hline & $\mathbf{A}$ & B & $\mathbf{C}$ & D & $\mathbf{E}$ & $\mathbf{F}$ & G & $\mathbf{I}$ & $\mathbf{J}$ & \\
\hline $\mathrm{N}$ & 44 & 34 & 48 & 43 & 39 & 31 & 45 & 44 & 49 & 377 \\
\hline SD & 14.54 & 9.19 & 11.73 & 6.58 & 12.34 & 16.62 & 8.68 & 10.03 & 12.39 & 11.90 \\
\hline \multirow[t]{2}{*}{ W.O.P. } & 86.6 & 92.2 & 90.2 & 95.7 & 93.9 & 84.7 & 91.9 & 91.9 & 87.5 & 90.6 \\
\hline & & 89.7 & & & 91.4 & & & 90.4 & & \\
\hline
\end{tabular}

Key:

$\mathrm{N}-$ the number of measurements

W.O.P. - nursing care quality coefficient

$\mathrm{SD}$ - Standard Deviation

A - The University Hospital in Krakow

B - Independent Public Teaching Hospital No 1 in Lublin

C - Independent Public Teaching Hospital

D - Provincial Hospital in Rzeszow
E - Stefan Cardinal Wyszynski Regional Hospital in Lublin

$\mathrm{F}$ - Jan Bozy Hospital in Lublin

G - SP ZOZ Kraśnik

$\mathrm{H}$ - Kruskal - Wallis H test

I - SP ZOZ Łuków

J - SP ZOZ Włodawa 
$33 \%$ wore protective gloves and $23 \%$ washed their hands $[11,12]$. The study by Worthington reveals that no single nurse did flush the ampoule containing a $0.9 \mathrm{NaCl}$ solution, prior to opening it and filling the single-use syringe with it [13].

Taxis et. al. made an analysis of nurses' work at three university hospitals in Germany and Great Britain showed that they failed to store intravenous therapy drugs in the places they were expected to. Instead, they kept these drugs on tables located near patients' beds. They also failed to disinfect the place where they prepared the solutions and disinfection of the vials was rather seldom as well $[14,15]$.

The authors' own research focused on adherence to aseptic standards reveals the following results $-3.1 \%$ of nurses at regional hospitals and 4.2 of nurses in provincial hospitals, as well as $5.6 \%$ of nurses at clinical hospitals did not wash or disinfect their hands prior to any procedures. Also, some $3.5 \%$ of nurses did not wear gloves during medical procedures. The staff employed at treatment facilities were more likely to do so than those employed at Intensive Therapy units or surgical wards. Some $17.5 \%$ of nurses were reported to store open container bottles in an improper way.

Glove manufacturing companies are researching the protection efficacy of gloves against viruses or bacteria. Gloves should defend healthcare professionals against blood, body fluids, secretion, excreta or contaminated instruments. Glove safety is checked in the procedure of viral testing which means checking the ease of microorganism transfer. Bacteriophages are used in this procedure, since they do not only have the same size as various bacteria but they are also easy to breed and safe enough to be used for research. In viral tests, the passage of bacteriophage (namely the quality of the barrier when subject to punctures). Those tests have shown that microorganism transfer is more likely in synthetic, rather than latex gloves. In case of nitrile and vinyl gloves, ethanolbased sanitizers are five times more likely to break through than in case of latex gloves. Also, these are five times more resistant to punctures than vinyl or nitrile gloves [16].

Wierzbińska has focused on the use of gloves and their role in cross-infection prevention [17].

The failures in the field of adherence to aseptic standards were as follows: $2.4 \%$ in regional hospitals, $5.3 \%$ in clinical hospitals and $4.0 \%$ in provincial hospitals. Usually, the staff washed or disinfected hands improperly and did not use gloves in the right way. This is compliant with findings of other authors.

Some modern methods of infection control are based on recognizing the scale of the phenomenon, discovering the causes of its high frequency, adopting the correct procedures and prevention standards, as well as overseeing the implementation process. These measures were among the first ones used to provide high-quality care. This means, tackling hospital-acquired infections means a quality improvement and lowering the treatment costs.

\section{CONCLUSIONS}

1. There is a $10 \%$ deficit in terms of adherence to aseptic procedures.

2. Constant supervision and upgrading nursing staff skills is essential.

\section{REFERENCES}

1. Golec M, Soluch S. Kompleksowe zarządzanie jakością w służbie zdrowia. Warszawa: Wydawnictwo KLIO; 2000.

2. Lenartowicz H. Zarządzanie jakością w pielęgniarstwie. Warszawa: Centrum Edukacji Medycznej; 1998.

3. Dobska M, Dobski P. TQM - zarządzanie przez jakość w zakładach opieki zdrowotnej. Poznań: Zakład Poligraficzny Mars Graf M. R. SójkaServmed; 2003.

4. Centers for Disease Control and Prevention. Guidance on Public Reporting of Healthcare -Associated Infections. Recommendations of the Healthcare Infection Control Practices Advisory Committee; 2005.

5. Kautsch M, Whitfield M, Klich J. Zarządzanie w opiece zdrowotnej: polsko-brytyjskie spojrzenie na zagadnienia zarządzania $\mathrm{w}$ ochronie zdrowia w nowym tysiącleciu. Kraków: Wydaw. Uniwersytetu Jagiellońskiego; 2001.

6. Fawcett-Henesy A. Quality Issues - the Nursing Role. Organizacja opieki pielęgniarskiej a zmiany w systemie ochrony zdrowia. Konferencja AM Lublin 7-8 maja 1993. Warszawa: Wyd. CEM; 1994.

7. Fawcett-Henessy A. Reformy systemów opieki zdrowotnej w Europie. Nowe wyzwania stawiane POZ. Pielęg. 1997;4(33):3-8.

8. Dzierżanowska D. Zakażenia szpitalne. Bielsko-Biała: ó- medica Press; 2008.

9. Fleischer M, Bober-Gheek B. Podstawy pielęgniarstwa epidemiologicznego. Warszawa: Centrum Kształcenia Podyplomowego Pielęgniarek i Położnych; 2006.

10. Romankiewicz E. Pilotażowe badania ryzyka zakażeń bakteryjnych przenoszonych przez ręce i odzież ochronną personelu medycznego. In: Piąta Ogólnopolska Konferencja - Jakość w opiece zdrowotnej. Kraków; 2000.

11. Fleischer M. Kontrola zakażeń w terapii dożylnej. Pielęgniarka Epidemiologiczna. Informator. Kwart Pol Stow Pielęg Epidemiol. 2006;4(27):12-22.

12. Leksowski K, Jasiński A, Marszałek A. Ocena skuteczności wybranych preparatów antyseptycznych stosowanych do dezynfekcji rąk przed zabiegami chirurgicznymi. Pol Merkuriusz Lek. 2001;11(62):151-3.

13. Worthington T, Tebbs S, Moss H, at al. Are contaminated flush solutions an overlooked source for catheter-related sepsis? J Hosp Infect. 2001;49:81-3.

14. Taxis K, Wirtz V, Barber N. Variations in aseptic techniques during preparation and administration of intravenous drugs - an observation-based study in the UK and in Germany. J Hosp Infect. 2004;56:79-81.

15. Frank U, Gastmeier P, Ruden H. The organization of infection control in Germany. J Hosp Infec. 2001;49:9-13.

16. Curran E. Reducing the risk of healthcare - acquired infection. Nurs Stand. 2001;16(1):45-52.

17. Wierzbińska M. Rękawice medyczne - profilaktyka zakażeń HBV, HCV, HIV. Zakażenia. 2005;5(6):71-2.

\section{Corresponding author}

Dr Marek Kos

13 Chopina Str., 23-200 Kraśnik

tel. 695-330-700

E-mail: marekkos@op.pl 